\title{
PERANAN PEMBINAAN KESEJAHTERAAN KELUARGA (PKK) DALAM UPAYA MEMPERTAHANKAN SIKAP KEKELUARGAAN MASYARAKAT KELURAHAN MANISREJO KOTA MADIUN
}

\author{
Priska Eka Putri Widya Yusila*
}

\begin{abstract}
Abstrak
$\mathrm{P}$ eranan PKK sangat penting bagi masyarakat khususnya untuk memperkuat rasa kekeluargaan bagi masyarakat sekitar terutama dilingkungan Manisrejo karena PKK adalah kunci utama untuk menyatukan masyarakat satu dengan yang lainnya dan menambah wawasan baru untuk masyarakat. Dengan programprogram kegiatan yang dibuat PKK secara tidak langsung akan membuat masyarakat akan sering berkumpul dan bertukar informasi antar satu dengan yang lain sehingga akan berdampak positif bagi masyarakat sekitar sekitar.

Penelitian ini menggunakan pendekatan kualitatif. Penentuan sampel di dalam penelitian ini menggunakan angket untuk mengukur kejujuran informan yang menjadi informan yaitu para kader PKK, dan masyarakat sekitar Lingkungan Manisrejo. Pengumpulan data menggunakan metode wawancara, observasi berperan dan dokumentasi. Analisis data yang digunakan data pendekatan deskriptif kualitatif dijabarkan dengan kata-kata, uraian maupun penafsiran. Sedangkan untuk keabsahan data dilakukan dengan memperpanjang masa pengamatan,melakukan observasi yang berkelanjutan, triangulasi, dan konfirmabilitas.

Hasil penelitian menunjukkan bahwa, Peranan pembinaan Kesejahteraan Keluarga (PKK) dalam upaya mempertahankan sikap kekeluargaan masyarakat di Kelurahan Manisrejo Madiun, Hal ini dibuktikan dengan hasil wawancara Ketua PKK, kader PKK dan warga masyarakat. Berdasarkan keseluruhan hasil wawancara mengungkapkan bahwa program-program kerja yang ada di dalam PKK Manisrejo memberikan banyak manfaat positif bagi masyarakat, selain memberikan program kerja para kader PKK juga aktif dalam lingkungan sekitar diantaranya banyak yang menjadi ketua RT maupun Ketua RW di masing-masing lingkungannya, juga menjadi pengurus arisan maupun kegiatan yang lain di masing-masing lingkungan. Dengan demikian hubungan masyarakat dengan pengus atau kader PKK menjadi lebih dekat dan hubungan antara masyarakat dengan masyarakat lebih baik sehingga rasa kekeluargaan di antara masyarakat di lingkungan Manisrejo menjadi lebih baik.
\end{abstract}

Kata Kunci: Peranan PKK, Kekeluargaan Masyarakat.

* Mahasiswa Prodi PPKn IKIP PGRI Madiun 
PENDAHULUAN

Dewasa Ketika manusia hidup berkelompok, secara internal terjadilah interaksi di antara anggota kelompok. Dalam kondisi seperti itu, sangat mungkin terjadi perbedaan pendapat, perselisihan, atau bahkan konflik diantara mereka. Kecuali itu dalam kenyataanya berbagai kelompok yang dijumpai dalam kehidupan bermasyarakat juga saling berinteraksi sama lain. Setiap kelompok memiliki kepentingan dan karakteristik tersendiri yang bukan tidak mungkin berbeda dengan kelompok lain. Kondisi seperti itu menuntut adanya "aturan main" yang disepakati bersama. Baik secara internal maupun eksternal. Secara internal, aturan yang dianggap baik oleh suatu kelompok dan kemudian disepakati untuk ditaati bersama lazim disebut norma. Norma didasarkan atas nilai-nilai tertentu. Yang menurut anggota kelompok dianggap baik atau positif dan mampu menyatukan mereka dalam kehidupan kelompok dan mampu menopang tercapainya tujuan kelompok. Norma menjadi acuan dalam kehidupan kelompok yang ditaati bersama.
Sekelompok orang yang hidup dalam suatu wilayah geografis tertentu terikat oleh norma tertentu yang disepakati bersama, dan memiliki tujuan bersama yang ingin dicapai, secara umum disebut masyarakat (society/community), dengan karakteristik yang melekat didalamnya.

Pengertian PKK menurut Rena (2012 : 1) memberikan pengertian PKK Pemberdayaan dan Kesejahteraan Keluarga adalah gerakan nasional dalam pembangunan masyarakat yang tumbuh dari bawah pengelolaanya dari, oleh, dan untuk masyarakat menuju terwujudnya keluarga yang beriman, dan bertakwa kepada Tuhan Yang Maha Esa, berakhlak mulia dan berbudi luhur, sehat sejahtera, maju dan mandiri.

Pengertian masyarakat sekelompok orang yang menempati suatu wilayah tertentu yang secara langsung atau tidak langsung saling berhubungan dalam usaha-usaha pemenuhan kebutuhannya, terikat sebagai suatu kesatuan sosial melalui perasaan solidaritas karena latar belakang sejarah politik dan kebudayaan. 
METODOLOGI PENELITIAN

Lokasi penelitian : lokasi penelitian ini dilaksanakan di Kelurahan Manisrejo Kecamatan Taman Kota Madiun.

Peranan

Pembinaan

Kesejahteraan Keluarga (PKK) dalam Upaya Mempertahankan Sikap Kekeluargaan Masyarakat yang ditetapkan sebagai obyek penelitian direncanakan selama 2 bulan yaitu bulan Desember sampai dengan Januari 2015.

Tehnik pengumpulan data :

a. Wawancara merupakan salah satu teknik pengumpulan data yang dilakukan dengan berhadapan secara langsung dengan yang di wawancarai tetapi dapat juga diberikan daftar pertanyaan dahulu..

b. Kuesioner atau angket merupakan suatu tehnik pengumpulan data denagan memberikan atau menyebarkan daftar pertanyaan kepada responden dengan harapan memberikan respon atau daftar pertanyaan tersebut. Daftar pertanyaan dapat bersikap terbuka, yaitu jika jawaban tidak ditentukan sebelumnya oleh peneliti dan dapat bersifat tertutup, yaitu alternatif jawaban telah ditentukan sebelumnya oleh peneliti. Adapun instrumen daftar pertanyaan dapat berupa pertanyaan berupa isian yang akan diisi oleh responden), checklist (berupa pilihan dengan cara memberi tanda pada kolom yang disediakan), dan skala ( berupa pilihan dengan memberi tanda pada kolom berdasarkan tingkat tertentu.

c. Pengamatan observasi tehnik ini menuntut adanya pengamatan dari peneliti baik secara langsung maupun tidak langsung terhadap obyek penelitian. Instrumen yang dapat digunakan yaitu lembar pengamat, panduan pengamatan.

d. Dokumen sejumlah besar fakta dan data tersimpan dalam bahan yang berbentuk dokumentasi.

\section{HASIL OBSERVASI}

Dari hasil observasi yang peneliti lakukan selama 2 (dua) bulan berturut-turut kepada masyarakat sekitar mengenai Peranan Pembinaan Kesejahteraan Keluarga (PKK) dalam Upaya Mempertahankan Sikap Kekeluargaan Masyarakat Kelurahan 
Manisrejo Kota Madiun menunjukkan bahwa adanya peran PKK dalam memberikan kegiatan-kegiatan, dan motivasi untuk masyarakat melalui kegiatan yang selalu mendorong masyarakat untuk selalu berorganisasi dengan masyarakat lain di lingkungan sekitar. Organisasi ini sangat membantu berperan penting dalam menumbuhkan sikap kekeluargaan di antara masyarakat. Sehingga akan menumbuhkan sikap saling tenggang rasa, saling menghargai, menghormati, rukun, (guyub) serta saling gotong royong sesama warga sekitar.

\section{Hasil Wawancara}

Tehnik dengan wawancara dan angket ini peneliti lakukan untuk mendapatkan data yang lebih banyak dan akurat dari pengamatan yang peneliti lakukan. Selama kurang lebih 2 (dua) bulan berturut-turut mengadakan wawancara dengan responden yang terdiri dari 5 pengurus PKK, 7 warga masyarakat.

Dari hasil wawancara yang peneliti lakukan terhadap sejumlah responden baik dengan tokoh masyarakat, dan pengurus PKK.
A. Peranan Pengurus PKK Kelurahan Manisrejo:

1) Pengajian: Ibu Dasno selaku ketua PKK kelurahan Manisrejo adalah kegiatan yang dilaksanakan oleh masyarakat baik itu yang dilaksanakan 1 bulan sekali ataupun 1 minggu sekali tergantung masing-masing RT. Beliau berpendapat setiap bulan selalu rutin dalam mengikuti pengajian dilingkungan dan selalu memotivasi masyarakat untuk mengikuti pengajian yang ada dilingkungan.

Arisan : Menurut ibu Dasno kegiatan yang selalu dilaksanakan oleh masyarakat masing-masing lingkungan setiap 1 bulan sekali, baik itu biasanya berupa arisan RT, maupun arisan RW. Beliau berpendapat selalu aktif dalam mengikuti kegiatan arisan. Dan memotivasi agar masyarakat untuk selalu aktif dalam kegiatan arisan.

Jimpitan: Menurut ibu Dasno kegiatan yang biasanya dana tersebut dipergunakan untuk 
keperluan lingkungan itu

sendiri ataupun untuk dana

sosial. Beliau berpendapat

selaku ketua PKK Manisrejo

juga ikut aktif memberikan

dana jimpitan untuk

kesejahteraan dilingkungan

dan selalu mendorong

masyarakat dan mendukung

guna untuk kepentingan dan

keperluan masyarakat itu

sendiri.

Rukun Kematian : Menurut

ibu Dasno kegiatan yang

membantu masyarakat yang

sedang terkena musibah,

apabila ada saudara yang

meninggal biasanya saling

gotong royong untuk saling

membantu. Beliau bependapat

selalu turut aktif di dalam

kegiatan rukun kematian.

Posyandu Lansia : Menurut

bu Dasno kegiatan posyandu

lansia kegiatan yang

diperuntukkan untuk para

lansia. Biasa ibu-ibu lansia di

beri pengetahuan tentang

kesehatan oleh petugas

kesehatan. Yang sangat

membantu untuk menambah

wawasan bagi para ibu-ibu lansia. Biasanya dilaksanakan

di Kelurahan tetapi di masing-

masing lingkungan juga ada.

Ibu Dasno kurang aktif di

dalam kegiatan posyandu

lansia dikarenakan memiliki

kesibukan bekerja.

Posyandu Balita : Menurut

$\mathrm{Bu}$ Dasno kegiatan yang

diperuntukkan bagi

masyarakat yang memiliki

anak di usia balita. Untuk

mengukur tumbuh kembang

anak. Yang biasanya

dilaksanakan di masing-

masing lingkungan RT

ataupun RW. Ibu Dasno

kurang aktif di dalam kegiatan

posyandu lansia dikarenakan

kesibukan bekerja.

2) Pengajian: Menurut Ibu Tutik Suparti sekretaris I Kelurahan

Manisrejo adalah kegiatan yang dilaksanakan oleh masyarakat baik itu yang dilaksanakan 1 bulan sekali ataupun 1 minggu sekali tergantung lingkungan masing-masing lingkungan. Menurut pendapat Ibu Tutik Suparti selaku Sekretaris I Kelurahan Manisrejo setiap 
bulan selalu rutin dalam mengikuti pengajian

dilingkungan. Dan selalu mendorong dan memotivasi masyarakat agar selalu mengikuti kegiatan pengajian karena selain mendapatkan barokah dalam pengajian juga akan lebih memperat sikap kekeluargaan antar masyarakat terutama di lingkungan tersebut.

Arisan : Menurut ibu Tutik kegiatan yang selalu dilaksanakan oleh masyarakat masing-masing lingkungan setiap 1 bulan sekali, baik itu biasanya berupa arisan RT, maupun arisan RW. Biasanya kegiatan arisan itu ada yang menetap di pos kampling (ruang pertemuan)

dilingkungan tersebut ada yang bergiliran di masingmasing rumah masyarakat. ibu Tutik berpendapat juga ikut aktif dalam mengikuti kegiatan arisan. Dan selalu memotivasi agar masyarakat untuk selalu aktif dalam kegiatan terlebih lagi dalam kegiatan arisan.
Jimpitan : Menurut ibu Tutik biasanya setiap masingmasing rumah diberi kaleng untuk wadah uang, yang biasanya mereka isi sebesar 500-2000. Setelah itu uang akan dikumpulkan menjadi satu untuk keperluan lingkungan dan digunakan untuk dana sosial. Menurut Ibu tutik beliau selalu rajin ikut serta dalam memberikan dana jimpitan. dan selalu mendorong masyarakat dan mendukung guna untuk kepentingan dan keperluan di dalam kegiatan masyarakat itu sendiri, serta keperluan untuk masing-masing lingkungan itu sendiri.

Rukun Kematian: Menurut ibu Tutik kegiatan yang membantu masyarakat yang sedang terkena musibah, apabila ada saudara yang meninggal biasanya saling gotong royong untuk saling membantu, mungkin seperti membantu memandikan jenazah, mengkafani ataupun membantu yang lainnya sesuai yang dibutuhkan, selain 
masyarakat lingkungan juga ikut serta membantu berupa dana ataupun perlengkapan yang dibutuhkan. Bu Tutik bependapat selalu turut aktif di dalam kegiatan rukun kematian.

Posyandu Lansia : Menurut bu tutik kegiatan posyandu lansia kegiatan yang diperuntukkan untuk para lansia. Biasanya ibu-ibu lansia di beri pengetahuan tentang kesehatan oleh petugas kesehatan. ibu tutik suparti juga selalu aktif di dalam mengikuti posyandu lansia.

Posyandu Balita : Menurut bu Tutik Suparti kegiatan posyandu balita kegiatan yang diperuntukkan untuk para ibuibu yang memiliki anak usia balita yang akan menimbang berat badan, tinggi badan, dan pertumbuhan balitanya. $\mathrm{Bu}$ Tutik bependapat selalu turut aktif di dalam kegiatan posyandu balita.

selalu mendorong dan menghimbau agar ibu-ibu lansia selalu aktif dalam mengikuti kegiatan posyandu lansia ini. Ibu Siswandi sendiri juga selalu aktif di dalam mengikuti posyandu lansia.

Posyandu Balita: Menurut ibu Siswandi kegiatan posyandu balita kegiatan yang diperuntukkan untuk para ibuibu yang memiliki anak usia balita yang akan menimbang berat badan, tinggi badan, dan pertumbuhan balitanya. Ibu Siswandi selalu mendorong masyarakat yang terlebih lagi yang memiliki anak balita untuk rajin mengikuti posyandu balita karena akan bermanfaat bagi anak balitanya. Meskipun begitu ibu Siswandi kurang aktif di dalam posyandu balita yang ada di kelurahan Manisrejo dikarenakan bukan kelompok kerja di bidang posyandu balita.

B. Partisipasi Masyarakat dalam Kegiatan Yang ada di

\section{Kelurahan Manirejo}

1) Pengajian : Menurut ibu $\begin{array}{lllll}\text { Sartini } & \text { RT } & 02 & \text { RW } & 01\end{array}$ mengatakan pengajian dilaksanakan 1 bulan sekali dan dirumah masyarakat 
apabila di kehendaki masyarakat dengan waktu yang bebas ditentukan masyarakat itu sendiri. Banyak masyarakat sekitar yang ikut berpartisipasi dalam kegiatan pengajian tersebut.

Arisan : Menurut ibu Sartini RT 02 RW 01 arisan dilingkungan tersebut biasanya digilir bergantian di rumah masyarakat sekitar. Partisipasi masyarakat sekitar di dalam mengikuti kegiatan arisan sangat baik. Banyak masyarakat yang ikut aktif dalam kegiatan arisan baik arisan RT maupun arisan RW.

Jimpitan : Di RT 02 RW 01 menurut ibu Sartini kegiatan jimpitan sangat bermanfaat bagi masyarakat sekitar dan lingkungan biasanya di lingkungan RT 02 RW01 jimpitan biasanya di dalam RT dilaksanakan 1 bulan sekali, sedangkan apabila di kelompok dilaksanakan setiap malam minggu. Biasanya dana dari kegiatan jimpitanjimpitan tersebut dari kegiatan jimpitan RT untuk membuat sejenis gudang untuk inventaris, dan apabila hasil dari jimpitan lingkungan biasanya digunakan untuk kegiatan lingkungan itu sendiri.

Rukun Kematian : menurut ibu Sartini apabila ada masyarakat yang sedang berduka biasanya datang melayat untuk membantu apa yang diperlukan bagi keluarga yang kesusahan seperti membantu untuk mengkafani memandikan jenazah ataupun kegiatan yang lain, apabila ada yang sakit biasanya datang menjenguk kerumah ataupun rumah sakit bila dirawat di rumah sakit. Apabila ada yang melahirkan biasanya datang menjenguk bayinya dan membawa keperluan untuk bayi.

Posyandu Lansia : Menurut ibu Sartini kegiatan posyandu lansia sangat bermanfaat karena sangat membantu untuk menambah pengetahuan dan wawasan tentang kesehatan yang biasanya diberikan langsung oleh 
petugas kesehatan. Biasanya ibu-ibu para lansia yang akan mengikuti posyandu lansia mengikuti di kelurahan Manisrejo.

\section{Posyandu Balita Dan Penyuluhan Vitamin A :} Menurut ibu Sartini kegiatan Posyandu balita biasanya ada di masing-masing lingkungan dan banyak para ibu-ibu yang memiliki balita datang untuk mengetahui tumbuh kembang balitanya. Di RT 02 RW 01 tempat posyandu balita dilaksanakan di posyandu lingkungn sekitar dan di RT 02 RW 01 memiliki kegiatan posyandu balita $1 \mathrm{RW}$ terdapat 2 posyandu. Dan biasanya 6 bulan sekali balita tersebut juga diberi vitamin $\mathrm{A}$ saat berlangsungya kegiatan posyandu balita.

2) Pengajian : Menurut ibu $\begin{array}{lllll}\text { Hartini } & \text { RT } & 06 & \text { RW } & 02\end{array}$ mengatakan selalu aktif mengikuti kegiatan pengajian bersama dilingkungan. Biasanya pengajian dilaksanakan di masjid ataupun bergantian dirumah masyarakat. Biasanya yang mengikuti pengajian adalah masyarakat dari berbagai macam RT yang masih satu wilayah di RW 02 Manisrejo. Menurut ibu Hartini banyak masyarakat yang aktif dalam mengikuti kegiatan pengajian.

Arisan : Menurut Ibu Sri Hartini selalu aktif dalam mengikuti kegiatan arisan bukan hanya ibu Hartini saja tetapi semua masyarakat juga aktif mengikuti arisan di lingkungan. Dan biasanya arisan RT dilaksanakan menetap di rumah salah satu warga Ketua RT dilingkungan RT 06 RW 02.

Jimpitan : Menurut ibu Sri Hartini kegiatan jimpitan sangat bermanfaat dan beliau selalu rajin dalam memberikan dana jimpitan, biasanya dana jimpitan di berikan saat kegiatan arisan berlangsung, dan dananya digunakan dana sosial dan guna kebutuhan lingkungan itu sendiri.

Rukun Kematian : Menurut ibu Sri Hartini beliau aktif didalam kegiatan rukun 
kematian. apabila ada yang meninggal masyarakat biasanya datang melayat untuk membantu apa yang diperlukan bagi keluarga yang kesusahan, apabila ada yang sakit biasanya datang menjenguk kerumah ataupun rumah sakit bila dirawat di rumah sakit. Apabila ada yang melahirkan biasanya datang menjenguk bayinya dan membawa keperluan untuk bayi.

Posyandu Lansia : Menurut ibu Sri Hartini biasanya ibuibu lansia datang baik itu di Kelurahan maupun di lingkungan Kelurahan tersebut untuk mengikuti kegiatan posyandu lansia. Menurut ibu

Sri Hartini kegiatan posyandu posyandu lansia sangat bermanfaat bagi masyarakat sekitar terutama bagi ibu-ibu lansia.

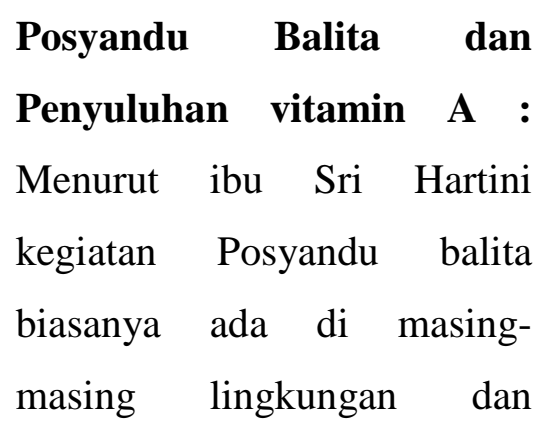

banyak para ibu-ibu yang memiliki balita datang untuk mengetahui tumbuh kembang balitanya. Biasanya tempat posyandu balita dilaksanakan di rumah masyarakat yang sedikit lebih besar. Dan biasanya 6 bulan sekali balita tersebut juga diberi vitamin A.

\section{PEMBAHASAN}

\section{a. Peranan pengurus PKK :}

Pengurus $r$ PKK
merupakan seseorang yang
mampu, tahu dan menggerakkan
apa yang sudah dibuat dan
disepakati bersama. Dari data
yang sudah di dapatkan saat
penelitian para pengurus PKK di
Kelurahan Manisrejo sudah
berusaha melaksanakan 10
program pokok PKK.

b. Peranan masyarakat :

Berdasarkan dari hasil penelitian yang diambil dari masing-masing RW di dalam kelurahan Manisrejo kebanyakan masyarakat 99 persen aktif dalam mengikuti kegiatan atau perkumpulan yang ada di lingkungan dan yang sisanya biasanya mereka tidak mengikuti 
kegiatan dikarenakan ada keperluan, kerja, sakit, ataupun capek sehingga mereka tidak mengikuti kegiatan. Dengan banyaknya jumlah masyarakat yang mengikuti kegiatan ataupun perkumpulan dilingkungan sekitar mereka sehingga mereka saling mengenal antar satu dengan yang lain, terutama bagi penduduk yang baru pindah atau menempati rumah di lingkungan Manisrejo lebih mudah beradaptasi.

Selain itu masyarakat juga memiliki tingkat kepedulian yang tinggi antar masyarakat dengan dilihat apabila ada tetangga mereka yang sakit mereka biasanya datang menjenguk ke rumah sakit apabila dirawat di rumah sakit ataupun dirumah mereka, biasanya mereka selain menjenguk juga membawa uang untuk mengurangi beban yang terkena musibah sakit biasanya menggunakan dana pribadi semampu mereka ataupun menngabungkan menjadi satu dengan warga lain. Apabila ada yang melahirkan biasanya mereka menjenguk kerumah sambil membawa bingkisan berupa kebutuhan perlengkapan bayi. Dan apabila ada yang meninggal biasanya rasa kepedulian antar masyarakat lebih tinggi biasanya masyarakat yang lain dilingkungan sekitar akan datang melayat dengan membantu apa yang dibutuhkan

Dengan tingginya rasa kepedulian antar masyarakat dan lingkungan akan menumbuhkan rasa sikap kekeluargaan yang tinggi antar masyarakat serta lingkungan akan membawa rasa kehidupan yang nyaman, aman dan damai.

\section{KESIMPULAN}

1. Dengan adanya berbagai macam kegiatan yang diberikan oleh PKK di Kelurahan Manisrejo Madiun sangat memberikan manfaat yang baik bagi masyarakat maupun lingkungan. Terutama dalam sikap kekeluargaan di masing-masing lingkungan sekitar. Karena seringnya masyarakat untuk selalu bersosialisasi satu dengan yang lain. 
2. Dan sosialisasi tersebut biasanya dengan mengikuti kegiatan seperti:

a. Arisan yang biasanya dilaksanakan 1 bulan sekali baik itu arisan dalam lingkup RT maupun arisan dalam lingkup RW. Dengan adanya kegiatan arisan yang dilaksanakan 1 bulan sekali dapat membuat masyarakat satu dengan yang lain bertukar informasi satu dengan yang lain. Dan lebih mudah untuk mengakrabkan diri.

b. Pengajian biasanya dilaksanakan 1 bulan sekali atau 1 minggu sekali tergantung masing-masing lingkungan RT biasanya dilaksanakan di rumah-rumah masyarakat ataupun di mushola sekitar lingkungan.

c. Jimpitan biasanya masingmasing rumah diberi kaleng untuk tempat uang yang akan mereka isi seikhlasnya yang sebesar 500-2000 biasanya dana jimpitan akan digunakan masing-masing lingkungan, Dan biasanya dipergunakan untuk keperluan yang dibutuhkan masing-masing lingkungan ataupun ada yang digunakan untuk membantu masyarakatnya yang mengalami musibah seperti sakit ataupun kematian.

d. Rukun Kematian biasanya membantu menolong warga masyarakatnya apabila mengalami musibah ada sanak saudara yang meninggal. Biasanya masyarakat bergotong royong untuk membantu apa saja yang dibutuhkan bagi keluarga yang membutuhkan.

e. Posyandu lansia biasanya dilaksanakan di kelurahan. Biasanya kebanyakan yang mengikuti kegiatan ini adalahah ibu-ibu lansia selain mendapat informasi kesehatan dari petugas kesehatan ibu-ibu lansia ini dapat bertukar informasi dengan yang lain. Sehingga dapat menambah informasi baru serta lebih mengakrabkan diri dengan ibu-ibu lansia yang lain.

f. Senam lansia hampir sama dengan posyandu lansia. Di kelurahan Manisrejo selain di 
Kelurahan di Masing-masing lingkungan RT juga diadakan senam lansia. Sehingga sikap kekeluargaan untuk para lansia juga lebih tinggi karena seringnya bertemu dalam kegiatan posyandu lansia dan di dalam senam lansia.

g. Posyandu balita biasanya dilakukan di masing-masing lingkungan RT biasanya ibuibu yang datang adalah masyarakat yang memiliki anak yang berusia balita. Kegiatan posyandu balita sangat memberi manfaat yang positif untuk masyarakat selain masyarakat dapat mengetahui tumbuh kembangnya anak mereka juga dapat bertukar informasiantar sesama masyarakat yang memiliki anak di usia balita.

\section{SARAN}

Dengan mengetahui gambaran mengeni Peranan Pembinaan Kesejahteraan Keluarga (PKK) dalam Upaya Mempertahankan Sikap Kekeluargaan Masyarakat di kelurahan Manisrejo, peneliti menyarankan :

1. Bagi pengurus PKK Pengurus PKK perlu meningkatkan kinerjanya lagi lebih aktif dalam memberikan motivasi dan dorongan kepada masyarakat. Serta pentingnya media komunikasi seperti Hp ataupun media komunikasi yang lain untuk lebih memudahkan antar sesama pengurus PKK untuk berkomunikasi

2. Bagi Masyarakat

Warga kelurahan Manisrejo Kecamatan Taman Kota Madiun hendaknya lebih turut aktif berpartisipasi terhadap kegiatankegiatan yang ada di lingkungan agar lingkungan lebih nyaman, aman dan masyarakat lebih rukun antar satu sama lain. Contoh yang sudah biasa yang dipergunakan seperti pengeras suara lewat mushola apabila ada tetangga yang mengalami musibah yang meninggal sehingga memudahkan warga masyarakat lain untuk mengetahui dan menolong. 
DAFTAR PUSTAKA

Djam'an Satori, Aan Komariah. 2012.

Metodologi Penelitian

Kualitatif. Bandung: Alfabeta.

Ismawati, Nur Siwi. 2007. 10

Program Kesejahteraan.

Klaten: Cempaka Putih.

Jhonson R.Lenny R. 2010.

Keperawatan Keluarga Plus

Contoh ASKEP Keluarga.

Yogyakarta: Nuha Medika.

Juliansyah Noor. Metodologi Penelitian. 2011. Jakarta: Kencana Prenada Media Group.

Muhyadi. 2012. Dinamika Organisasi

Konsep dan Aplikasinya dalam Interaksi Sosial. Yogyakarta: Ombak.

Rena. 2013 Pengertian PKK pkkkelurahanpandurenan.blog spot.co.id/2013/03/pengertiantujuan-dan-sasaranpkk.html.(Diakses pada tanggal 16 Nopember 2015).

Sugiyono. 2013. Metode Penelitian

Kuantitatif Kualitatif dan R\&D.Bandung: Alfabeta.

Suharsimi Arikunto. 2006. Prosedur Penelitian Suatu Pendekatan Praktik (Suatu Edisi Revisi VI).Jakarta: Rineka Cipta.

Tim Penulis Sosiologi. Sosiologi 1. 1997. Bandung: PT Remaja Rosdakary

Yadi Setiawan. 2011. Fungsi Masyarakat dalam Kehidupan blogspot.co.id./2011/11/fungsi -masyarakat-dalam-
kehidupan.html.(Diakses

tanggal 15 Nopember 2015 